\title{
A morphotype catalog and paleoenvironmental interpretations of early Miocene fossil leaves from the Hiwegi Formation, Rusinga Island, Lake Victoria, Kenya
}

\author{
Daniel P. Maxbauer, Daniel J. Peppe, Marion Bamford, Kieran P. McNulty, \\ William E.H. Harcourt-Smith, and Larry E. Davis
}

\begin{abstract}
Early Miocene deposits on Rusinga Island (Lake Victoria, Kenya) contain an abundance of faunal and floral remains. Despite the attention that has historically been given to the early Miocene fauna from Rusinga Island, little attention has been given to the early Miocene fossil floras and to date no studies have described fossil leaf morphotypes from Rusinga Island. Here, we present a morphotype catalog of fossil leaves collected from the Grit Member of the Hiwegi Formation on Rusinga Island. We describe 14 morphotypes, comprised of 12 dicotyledonous angiosperms and two monocotyledonous angiosperms, as well as two distinct dicotyledonous angiosperm leaf fragments. Characteristics of the flora and sedimentological evidence, coupled with previous research, suggest that the local paleoenvironment was a riparian habitat within a patchwork of woodland and forested biomes in what was likely a warm climate. This work represents an important first step in understanding the early Miocene vegetation of Rusinga Island, and highlights both the need and potential for future research on these early Miocene floras.
\end{abstract}

Daniel P. Maxbauer. Department of Biology, Saint John's University, Collegeville, Minnesota, USA and Department of Earth and Environmental Sciences, Wesleyan University, Middletown, Connecticut, USA and Department of Earth Sciences, University of Minnesota, Minneapolis, Minnesota, USA maxba001@umn.edu

Daniel J. Peppe. Department of Geology, Baylor University, Waco, Texas, USA daniel_peppe@baylor.edu Marion Bamford. Bernard Price Institute for Palaeontology, University of the Witwatersrand, Johannesburg, South Africa Marion.Bamford@wits.ac.za

Kieran P. McNulty. Evolutionary Anthropology Lab, Department of Anthropology, University of Minnesota, Minneapolis, Minnesota, USA kmcnulty@umn.edu

William E.H. Harcourt-Smith. Department of Anthropology, Lehman College CUNY, Bronx, New York, USA and Department of Anthropology, Graduate Center CUNY, New York, New York, USA willhs@amnh.org and Division of Paleontology, American Museum of Natural History, New York, New York, USA Larry E. Davis. Department of Biology, Saint John's University, Collegeville, Minnesota, USA Idavis@csbsju.edu

PE Article Number: 16.3.28A

Copyright: Palaeontological Association November 2013

Submission: 10 August 2013. Acceptance: 5 November 2013

Maxbauer, Daniel P., Peppe, Daniel J., Bamford, Marion, McNulty, Kieran P., Harcourt-Smith, William E.H., and Davis, Larry E. 2013. A morphotype catalog and paleoenvironmental interpretations of early Miocene fossil leaves from the Hiwegi Formation, Rusinga Island, Lake Victoria, Kenya, Palaeontologia Electronica Vol. 16, Issue 3; 28A; 19p; palaeo-electronica.org/content/2013/547-rusinga-island-flora 
Keywords: early Miocene; Rusinga Island; megafloral paleobotany; paleoenvironment

\section{INTRODUCTION}

Fossil collections from the early Miocene deposits on Rusinga Island, Lake Victoria, Kenya (Figure 1) provide some of the best evidence of East African paleocommunities immediately following the connection of Africa to Eurasia (e.g., Savage, 1965; Pickford, 1986, 2004; Schmidt-Kittler, 1987; Cote et al., 2007; Drake et al., 1988; Peppe et al., 2009; Peppe et al., 2011). Rusinga Island is particularly well known for its abundant well-preserved fossil catarrhine primates, Proconsul, Nyanzapithecus, Limnopithecus, and Dendropithecus (e.g., Maclnnes, 1943; Le Gros Clark and Leakey,
1950; Andrews and Simons, 1977; Walker et al., 1993). However, these early Miocene deposits also contain an abundance of plant fossils. Despite this, only a few studies from Rusinga Island have focused on fossil plant remains (e.g., Chesters, 1957; Collinson, 1985; Collinson, et al., 2009), and none has focused on fossil leaves. Since leaves cannot be transported intact over great distances, fossil leaves are often excellent indicators of local environment. Historical collections on Rusinga Island have yielded mostly fragmentary or poorly preserved megafloral material (e.g., Kent, 1994; Collinson et al., 2009), and this paucity of specimens and research highlights the need for further
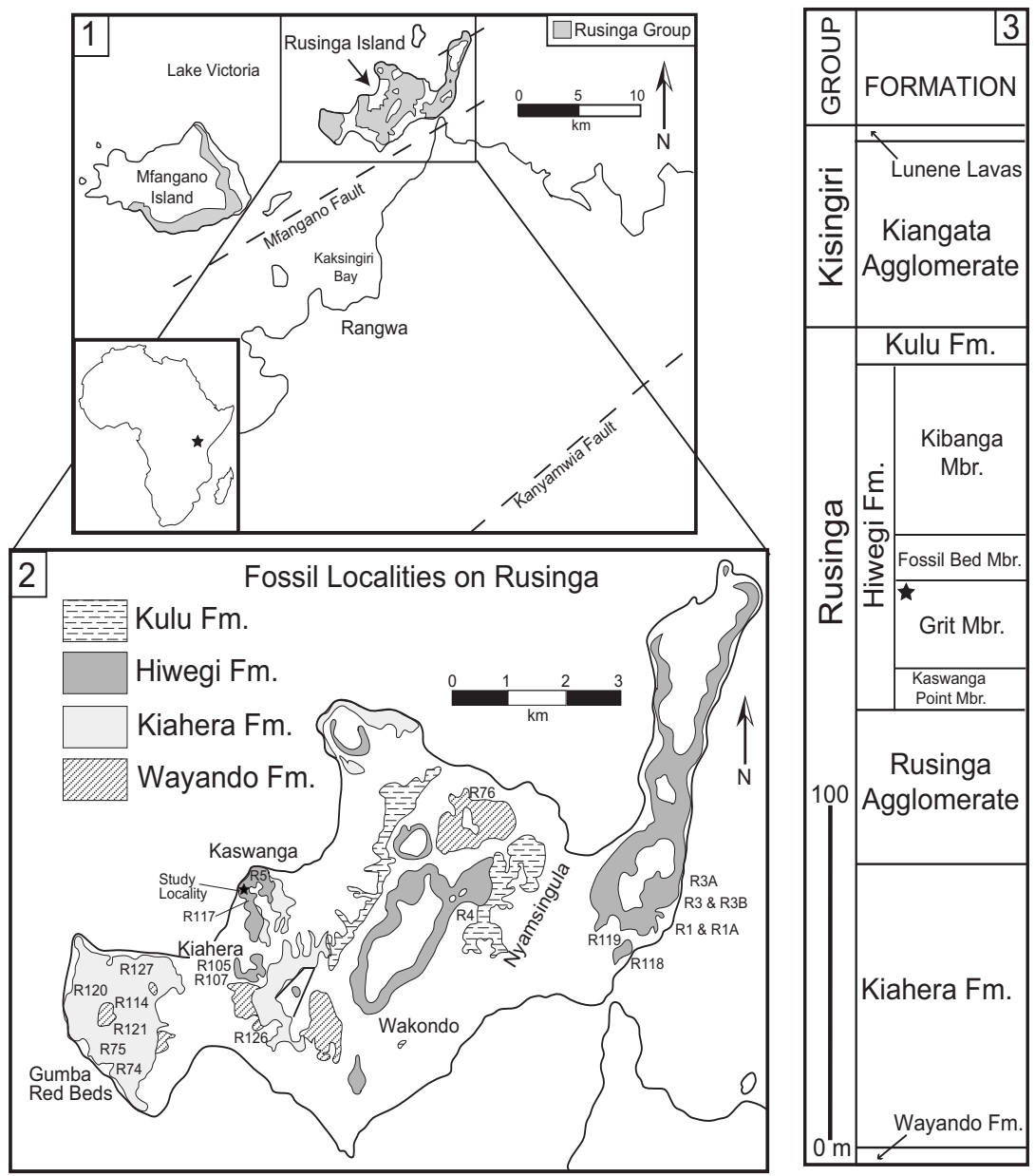

FIGURE 1. 1. A map showing Africa, star indicates approximate location of Lake Victoria, Rusinga Island and Mfangano Island. 2. Generalized map of Rusinga Island including basic stratigraphic distributions and general site locations. Star indicates the approximate location of this studies location. GPS coordinates for the study site: $\mathrm{S} 00^{\circ}$ 24.350' E $034^{\circ} 8.834^{\prime}$. 3. Generalized Miocene stratigraphy on Rusinga Island. Star indicates stratigraphic position of fossil leaf locality. Mbr. = member, Fm. = formation. 
studies into Rusinga Island's early Miocene megaflora and their associated terrestrial environments.

Here, we document the first assemblage of fossil leaf morphotypes collected on Rusinga Island from a restricted stratigraphic interval within the Grit Member of the Hiwegi Formation (Figure 1). We then present a paleoenvironmental interpretation based on the flora and the sedimentology within the collection area.

\section{Geological Setting and Previous Paleoecological Work}

Geological history and stratigraphy. Today, Rusinga Island resides on what was once the flank of the large carbonatite-nephelinite Kisingiri Volcano, which formed in the early Miocene in association with the failed Nyanza Rift (Figure 1). These Miocene deposits pre-date the formation of Lake Victoria (see review of Lake Victoria's history in Danley et al., 2012). The stratigraphic nomenclature used here follows Peppe et al. (2009) and Van Couvering (1972) (Figure 1). K-Ar dates published by Drake et al. (1988) suggested that the Hiwegi Formation was deposited $\sim 17.9 \mathrm{Ma}$, and that the entire fossiliferous Rusinga Group sequence (Figure 1) was deposited in less than a half million years. More recent analyses using ${ }^{40} \mathrm{Ar} / 39 \mathrm{Ar}$ dates, magnetostratigraphy, and lithostratgiraphy demonstrate that the fossiliferous strata on Rusinga were deposited over a much longer time interval, between $\sim 17-20$ Ma (Peppe et al., 2009; Peppe et al., 2011; McCollum et al., 2012).

Previous Paleoecological and Paleobotanical Work. Paleoenvironmental reconstructions from various proxies have yielded contradictory results, with interpretations ranging from tropical rain forest to woodland to a semi-arid climate (Chesters, 1957; Andrews and Van Couvering, 1975; Evans et al., 1981; Collinson, 1985; Thackray, 1994; Retallack et al., 1995; Bestland and Krull, 1999; Forbes et al., 2004; Collinson et al., 2009; Ungar et al., 2012). Many studies have examined data from the entire Hiwegi Formation (e.g., Andrews and Van Couvering, 1975; Evans et al., 1981; Retallack et al., 1995; Forbes et al., 2004; Ungar et al., 2012), which may span >100 kyr (Peppe et al., 2011; McCollum et al., 2012). Hence, these studies likely sampled a mixture of environments from different time periods during the deposition of the Hiwegi Formation. Alternatively, work by Collinson (1985), Collinson et al. (2009), and Thackray (1994) was based on restricted stratigraphic intervals and therefore report estimates of paleoclimate and paleoenvironments from narrow slices of time.
These different types of datasets (stratigraphically restricted vs. time-averaged) may help to explain the range of paleoenvironmental interpretations that persist in the literature.

To date, only three studies have focused exclusively on plant fossils from Rusinga deposits. Chesters (1957) examined primarily fossil wood and seeds from Rusinga and Mfangano Islands and suggested that the early Miocene paleoenvironment of the region was a tropical rain forest or gallery forest near a river margin. However, because the fossil material used in the analyses was derived from surface collections from multiple sites of different ages, these results may not be reliable. Collinson et al. (2009) and Collinson (1985) used nearest living relative (NLR) analyses on in situ fruits, seeds, wood of dicotyledonous angiosperm trees, shrubs, herbaceous and woody climbers, and the fruit of a monocotyledonous palm. In contrast to Chesters (1957), they concluded that the local paleoenvironment studied was a woodland with limited forest present. This interpretation was based largely on the determination that the flora consisted of only $4.2 \%$ definitively forest dwelling taxa, belonging to 3 of the 21 families represented by their assemblage (see Collinson et al., 2009 for complete taxon list). Unlike the Chesters (1957) study, these analyses were from a single stratigraphic unit in the Grit Member and are more likely to reflect the local paleoenvironment.

Study Area. For this study, the fossil leaves come from a site near the R5 vertebrate fossil locality at Kaswanga Point (Figure 1), in close proximity to the fossil site R117 described in Collinson (1985) and Collinson et al. (2009) (Figure 1). Both our study area and locality R117 are within the Grit Member, and probably are roughly contemporaneous. However, the exact location of the R117 flora and its stratigraphic position in the Grit Member is uncertain, making a direct correlation between our study area and R117 impossible at this time.

At the study area, five distinct stratigraphic layers of the Grit Member were exposed, measured, and described (Figure 2, Table 1). Each layer was assigned a number (to indicate stratigraphic relationship) preceded by "GM". Fossil leaves were collected from level GM-02. Many of the leaves are fragmentary and often conform to the rippled bedforms in layer GM-02 preventing the leaves from being flat-lying. Ripple marks (Figure 3.1) identified in GM-02 and GM-05 indicate the presence of moving water, whereas salt hoppers (Figure 3.2) and desiccation cracks in bed GM-03 indicate periodic aerial exposure, desiccation, and 

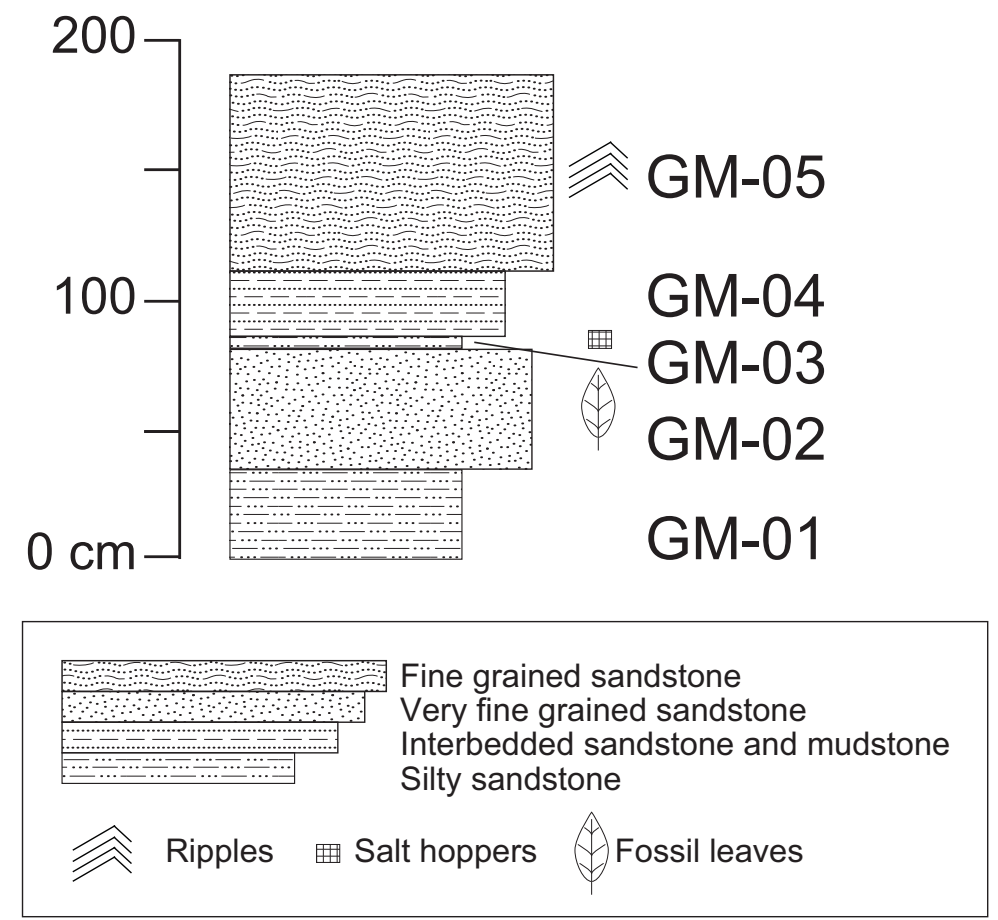

FIGURE 2. Stratigraphic section of the Grit Member exposed at fossil leaf locality. Ripple marks were found in GM-05, salt hoppers in GM-03, and fossil leaves in GM-02. GM = Grit Member.

evaporitic conditions. The fragmentary nature of the leaves, their preservation on rippled bedforms, and the fluvial indication in layer GM-02, suggest that the fossil leaves may have been transported a short distance before being deposited.

\section{METHODS}

The fossil leaves were collected from a tuffaceous sandstone layer, GM-02, in the Grit Member (Figure 2, Table 1). All samples were collected in July 2010 and are housed at the National Museums of Kenya, Nairobi (NMK). Specimens were grouped according to morphological characteristics and assigned to a morphotype. Morphotypes are morphologically distinct groups of specimens that have no formal taxonomic status but often reflect biological species (see review of the morphotyping method in Ash et al., 1999 and Peppe et al., 2008). The specimen that best represented the characteristics of each morphotype and/or showed the highest level of preservation was chosen to be the morphotype exemplar. Specimen numbers listed here coordinate with the catalog numbers of specimens housed at the NMK (Appendix 1). Those specimens that were not identifiable to an existing morphotype or were too fragmented to be placed in a new category were marked as unidentifiable and

TABLE 1. Descriptions of stratigraphic layers of the exposed section of the Grit Member (GM) at the study site.

\begin{tabular}{ccl} 
Layer & $\begin{array}{c}\text { Thickness } \\
(\mathbf{c m})\end{array}$ & \\
\hline GBM-05 & 70 & Bluish, greenish light grey. Fine to very fine sandstone. Ripple marks present. \\
GBM-04 & 25 & Greenish light grey. Finely laminated, medium fine sandstone, mudstone. \\
GBM-03 & 1 & Dark grey. Silty sandstone that in areas shows signs of mud cracks. \\
GBM-02 & 40 & $\begin{array}{l}\text { Greenish light grey. Fine grained sandstone. Massively bedded. Organic material, } \\
\text { including leaves, was found within this layer. }\end{array}$ \\
GBM-01 & 30 & Dark grey. Fine grained silty sandstone.
\end{tabular}




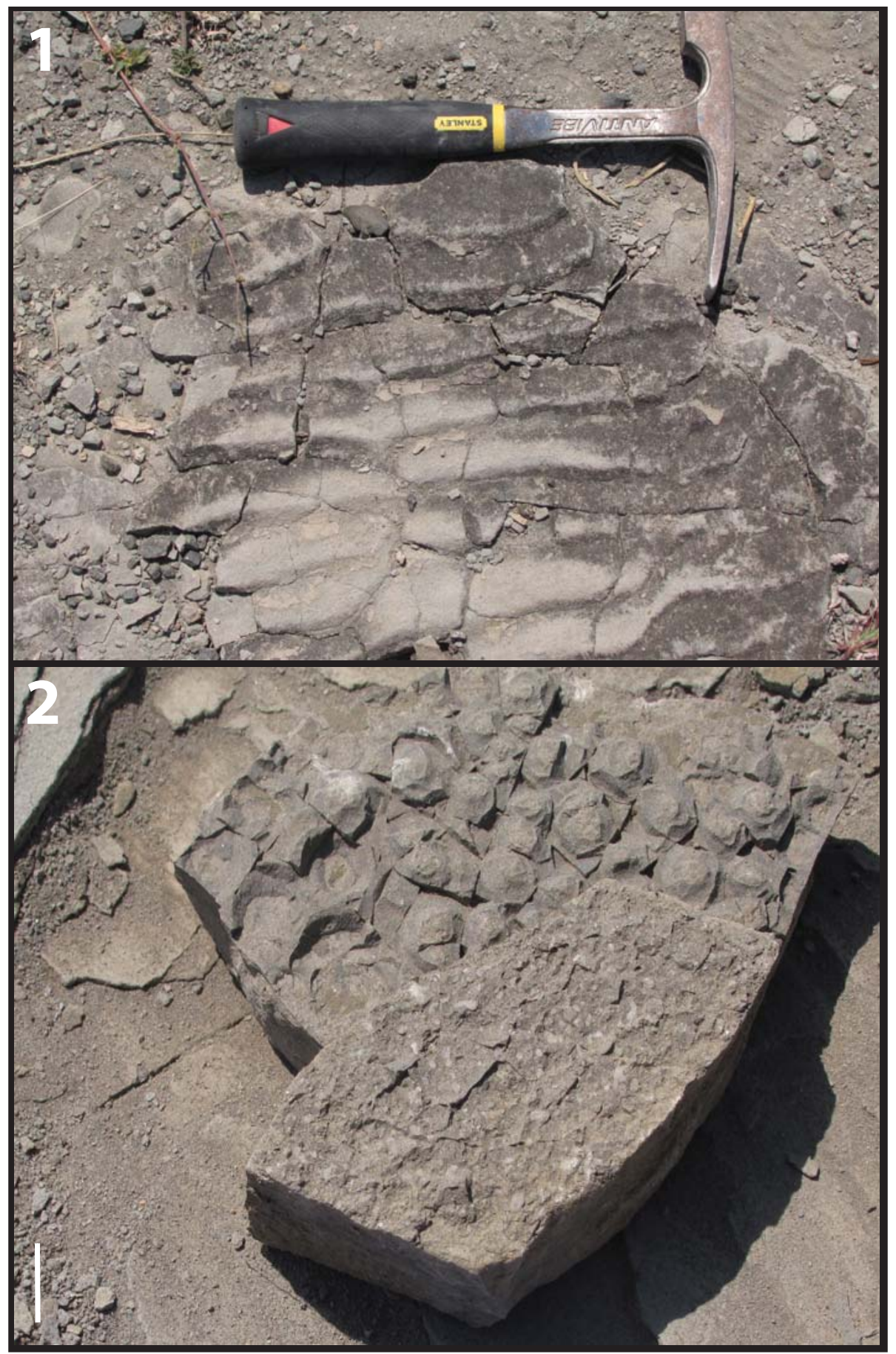

FIGURE 3. 1. Ripple marks a top GM-05. 2. Salt hoppers from GM-03. Scale bar = $1 \mathrm{~cm}$.

grouped together under one specimen and catalog number. No taxonomic affinities have been determined at this time for the dictolydenous angiosperms. This morphotype catalog is intended instead to act as an important first step in documenting the poorly studied Rusinga Island megaflora.
Morphotypes were described following the well-established protocols of Ellis et al. (2009). Each morphotype description adheres to the following format:

Description: Blade attachment, laminar size, length:width $(\mathrm{L}: \mathrm{W})$ ratio, laminar shape, medial symmetry, and basal symmetry. Margin type, apex 
angle, apex shape, base angle, and base shape. Primary vein framework, naked basal veins, number of basal veins, and agrophic veins. Major secondary vein framework, major secondary spacing, variation of secondary angle, major secondary attachment. Interior secondaries, minor secondary course, and perimarginal veins. Intersecondaries proximal course, length, distal course, and vein frequency. Intercostal tertiary vein fabric, angle of percurrent tertiaries, vein angle variability. Quaternary vein fabric.

(Note: If a category is missing from a description, then that characteristic is currently unknown due to incomplete preservation. Also, where a described feature is not evident from the specimen photograph or illustration, that feature was observed in a non-exemplar specimen referred to that morphotype that is not figured here.)

\section{MORPHOTYPE CATALOG}

\section{Dicotyledonous angiosperms}

$$
\mathrm{KP}-01
$$

\section{Figures 4.1-4.3}

Description: Blade attachment marginal. Laminar size microphyll, laminar shape elliptic with medial symmetry and base symmetric to slightly asymmetric. Margin is entire with acute apex angle, unknown apex shape, acute base angle, and cuneate base shape. Primary venation is pinnate with no naked basal veins, one basal vein, and no agrophic veins. Major secondaries simple brochidodromous with irregular spacing increasing basally, uniform secondary angles, and excurrent secondary attachment to midvein.

Morphotype exemplar: RU-2010-849 (Figure 4.1) Additional specimens: RU-2010-832-836, RU2010-864, RU-2010-865, RU-2010-857, RU-2010858, RU-2010-852, RU-2010-853

Discussion: The brochidodromous secondaries, irregular secondary spacing, uniform secondary angles, and cuneate base shape characterize this morphotype. KP-01 is morphologically similar to KP-06, however it can be distinguished based on its elliptic laminar shape, cuneate base shape, higher angle of divergence of its secondary veins from the primary vein, and its irregularly spaced major secondaries.

$$
\mathrm{KP}-02
$$

\section{Figures $4.4,4.5$}

Description: Blade attachment marginal, laminar size microphyll, L:W ratio approximately 2:1, laminar shape likely oblong or elliptic. Margin entire with unknown apex, obtuse base angle, and cordate base shape. Primary venation is pinnate with present naked basal veins, at least four basal veins, and no agrophic veins. Major secondaries brochidodromous with spacing decreasing proximally, secondary angles abruptly increase proximally, and excurrent attachment to midvein. Interior secondaries absent, and minor secondaries absent. Intercostal tertiaries irregular reticulate.

Morphotype exemplar: RU-2010-838 (Figure 4.4)

Discussion: The prominent midvein, naked basal veins, and cordate base shape clearly distinguish $\mathrm{KP}-02$ as a unique morphotype.

$$
\mathrm{KP}-03
$$

Figures 5.1-5.4

Description: Blade attachment marginal, laminar size microphyll, L:W ratio approximately $2: 1$, laminar shape ovate to elliptic with medial symmetry. Margin entire with acute apex angle, straight apex shape, and unknown base. Primary venation is pinnate. Major secondaries eucamptodromous becoming brochidodromous distally with irregular spacing, angles variable, and excurrent attachment to midvein. Secondary veins are highly ascending; secondary angles range from $38-45^{\circ}$. Intersecondaries span less than $50 \%$ of the length of the subjacent secondary, occur usually one per intercostal area, with a course perpendicular to midvein. Intercostal tertiaries straight opposite percurrent with obtuse angle, and uniform angle variability. Quaternary vein fabric regular reticulate.

Morphotype exemplar: RU-2010-267 (Figure 5.1) Additional specimens: RU-2010-839, RU-2010841

Discussion: The distinct, abundant intersecondaries and highly ascending secondary venation characterize this morphotype. KP-03 and KP-04 are morphologically similar; however the highly ascending curvature of the major secondaries in $\mathrm{KP}-03$ is markedly different than that of KP-04. Additionally, intersecondary veins are very common and are perpendicular to the midrib in KP-03, whereas in KP-04 intersecondaries are rare and follow a course parallel to the major secondaries.

$$
\text { KP-04 }
$$

Figures 5.5, 5.6

Description: Blade attachment marginal, laminar size microphyll, laminar shape elliptic with medial symmetry, and basal symmetry. Margin entire with unknown apex, acute base angle, and rounded to cordate base shape. Primary venation is pinnate with no naked basal veins, one to three basal veins, and no agrophic veins. Major secondaries 

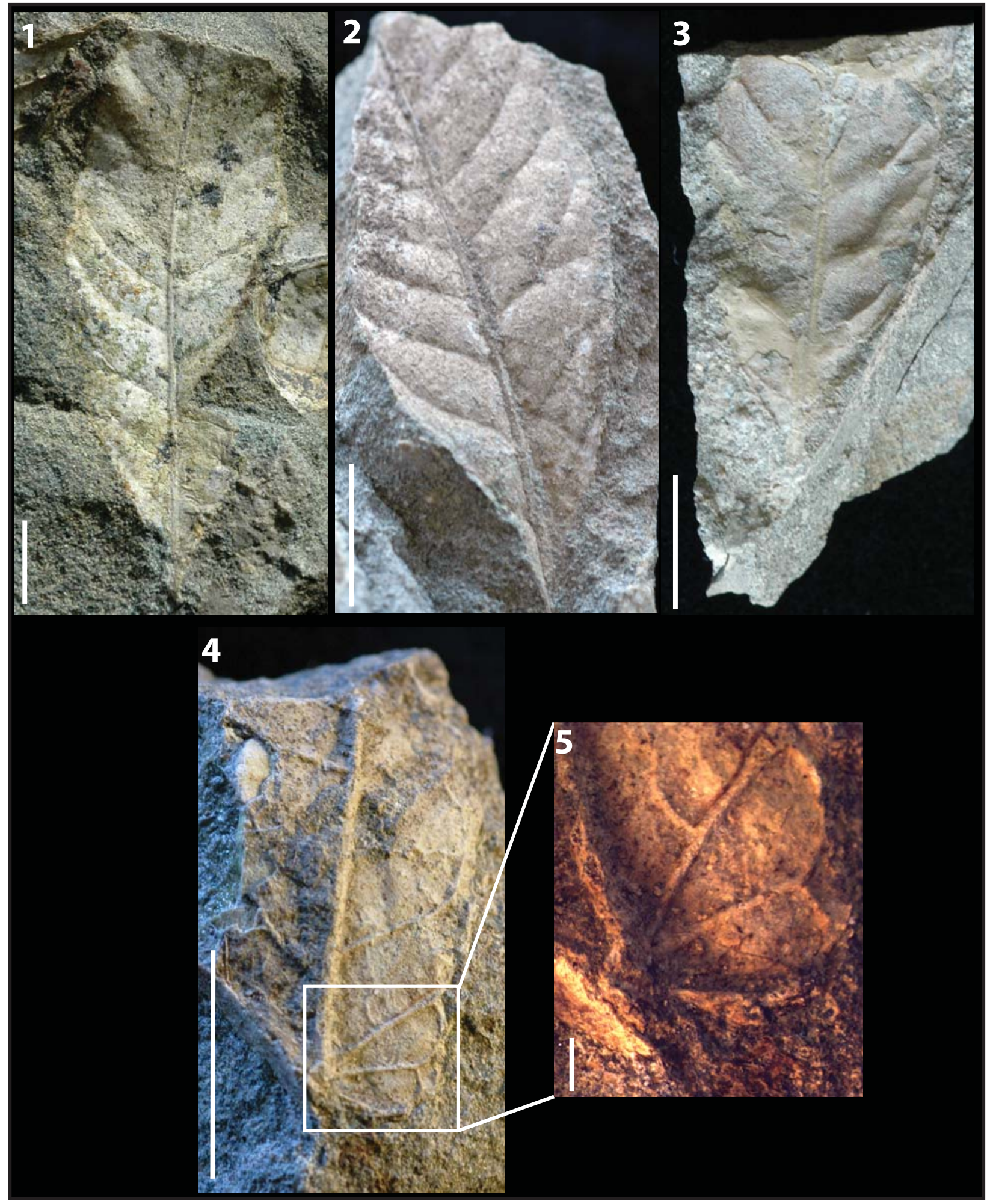

FIGURE 4. 1. Morphotype exemplar for KP-01, RU-2010-849. 2. RU-2010-864. 3. RU-2010-853. All specimens in 4.1-4.3 belong to KP-01 and display brochidodromous secondary venation, elliptic laminar shape, and cuneate base shape. 4. KP-02 morphotype exemplar, RU-2010-838, leaf showing oblong laminar shape, cordate base, pinnate primary venation, and brochidodromous secondary venation. All scales in 4.1-4.4 = $1 \mathrm{~cm}$. 5. Enlarged portion of 4.4 showing cordate base with a naked basal vein, at least four basal veins, and brochidodromous secondary venation. Scale $=2 \mathrm{~mm}$. 


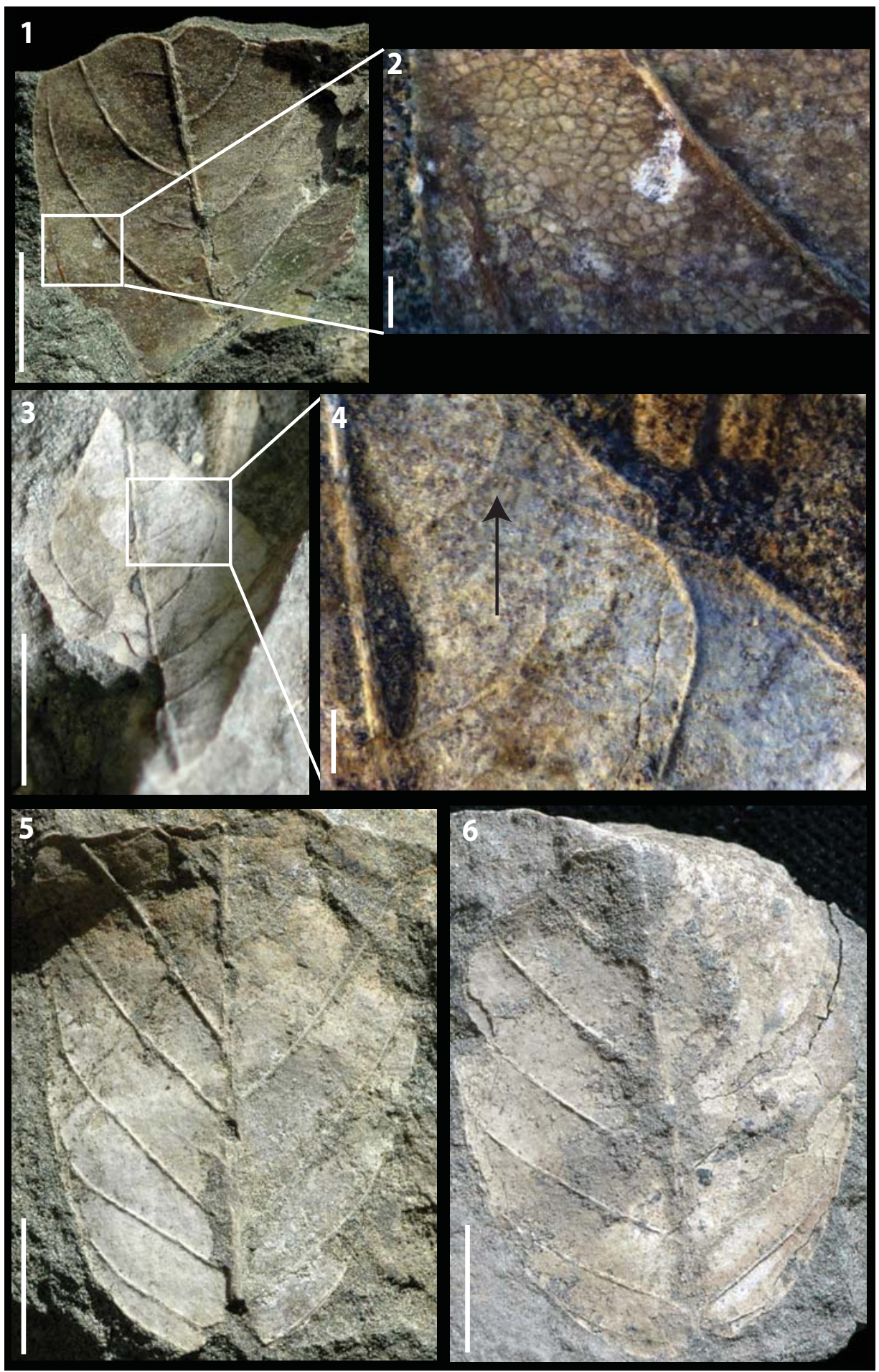

FIGURE 5. 1. KP-03 morphotype exemplar, RU-2010-267, showing eucamptodromous secondaries, highly ascending secondary angle, and abundant intersecondaries. Scale bar $=1 \mathrm{~cm}$. 2. Enlarged portion of 5.1 showing straight opposite percurrent intercostal tertiaries and regular reticulate quaternary vein fabric. Scale $=2 \mathrm{~mm}$. 3. RU-2010-839, leaf shows the diagnostic highly ascending secondaries unique to KP-03 along with the ovate laminar shape and straight apex shape. Scale bar $=1 \mathrm{~cm}$. 4. Enlarged portion of 5.3 showing major secondaries becoming brochidodromous distally. Scale $=2 \mathrm{~mm}$. 5. KP-04 morphotype exemplar, RU-2010-840, showing eucamptodromous secondary venation, low angle of divergence of secondaries that turn up abruptly near margin, and cordate base shape. Scale $=1 \mathrm{~cm}$. 6 . RU-2010-842, further showing the diagnostic secondary vein course and cordate base shape characteristic of KP-04. Scale $=1 \mathrm{~cm}$. 
eucamptodromous with irregular spacing, uniform angles, and excurrent attachment to midvein. Intersecondaries span less than $50 \%$ of the length of the subjacent secondary, occur less than one per intercostal area, with course parallel to the major secondaries. Intercostal tertiaries straight opposite percurrent with obtuse angle, and uniform angle variability. Quaternary vein fabric regular reticultate.

Morphotype exemplar: RU-2010-840 (Figure 5.5) Additional specimens: RU-2010-842, RU-2010843, RU-2010-985, RU-2010-986

Discussion: The morphotype is characterized by its cordate to rounded base shape, rare intersecondary veins that are parallel to the major secondary veins, and secondary veins that diverge from the primary vein at a low angle and turn up abruptly near the margin. As discussed above, KP-04 can be distinguished from KP-03 based on the course of its major secondary veins, particularly near the midvein, and the characteristics of its intersecondaries.

$$
\text { KP-05 }
$$$$
\text { Figure } 6
$$

Description: Blade attachment marginal, laminar size mesophyll, L:W ratio 1.8:1, laminar shape ovate to elliptic with medial symmetry, and apparent basal symmetry. Margin entire with unknown apex, acute base angle, convex to rounded base shape. Primary venation is pinnate with no naked basal vein, and simple agrophic veins. Major secondaries brochidodromous with spacing regular, uniform angle, and excurrent attachment to midvein. Minor secondaries course simple brochidodromous. Intersecondaries span less than 50\% of the length of the subjacent secondary, occur roughly one per intercostal area, with course parallel to major secondaries. Intercostal tertiaries opposite sinuous percurrent with obtuse angle, and inconsistent angle variability.

Morphotype exemplar: RU-2010-844 (Figures 6.1, 6.2)

Discussion: The combination of a mesophyll lamina, agrophic veins, minor secondaries, and sinuous percurrent tertiary veins with very obtuse angles distinguishes this morphotype.

\section{$\mathrm{KP}-06$ \\ Figure 7}

Description: Blade attachment marginal, laminar size mesophyll, L:W ratio $2: 1$, laminar shape oblong to elliptic with medial symmetry. Margin is entire with acute apex angle, convex to straight apex shape, acute base angle, and convex base shape. Primary venation is pinnate with no naked basal veins, at least two basal veins, and no agrophic veins. Major secondaries brochidodromous with irregular spacing, irregular angles, and excurrent attachment to the midvein. Intersecondaries span less than $50 \%$ of the length of the subjacent secondary, occur less than one per intercostal region, course is perpendicular to the midvein. Intercostal tertiaries sinuous percurrent with angles varying from perpendicular to obtuse.

Morphotype exemplar: RU-2010-845 (Figure 7.1) Additional specimens: RU-2010-846, RU-2010987, RU-2010-862

Discussion: The oblong shape, mesophyll size of the lamina, the angle of divergence of the intersecondary veins, and the variation of angle in the intercostal tertiaries from perpendicular to obtuse distinguish this morphotype.

$$
\text { KP-07 }
$$

Figures 8.1, 8.2

Description: Blade attachment marginal, laminar size microphyll, L:W ratio 4:1, laminar shape ovate with medial symmetry and base symmetric to slightly asymmetric. Margin is entire with acute apex angle, unknown apex shape, base angle acute, and concave base shape. Primary venation is pinnate with no naked basal veins, three basal veins, and no agrophic veins. Major secondaries brochidodromous with regular spacing increasing basally, uniform angles, and excurrent attachment to midvein. Intersecondary veins common and span less than $50 \%$ of the length of the subjacent secondary, occur roughly one per intercostal area, proximal course is perpendicular to midvein. Rare epimedial tertiary veins. Intercostal tertiaries are mixed percurrent with obtuse angles and uniform angle variability.

Morphotype exemplar: RU-2010-848 (Figure 8.1)

Description: The ovate shape, the 4:1 length-towidth ratio, combined with brochidodromous secondary venation and common intersecondary veins distinguish this morphotype.

$$
\begin{gathered}
\text { KP-08 } \\
\text { Figure } 8.3
\end{gathered}
$$

Description: Blade attachment marginal, laminar size mesophyll, L:W ratio 3.25:1, laminar shape elliptic to oblong with medial symmetry. Margin is entire with acute apex angle, straight apex, acute base angle, and unknown base shape. Primary venation is pinnate. Major secondaries weak brochidodromous with regular spacing, uniform angles, and excurrent attachment to midvein.

Morphotype exemplar: RU-2010-860 


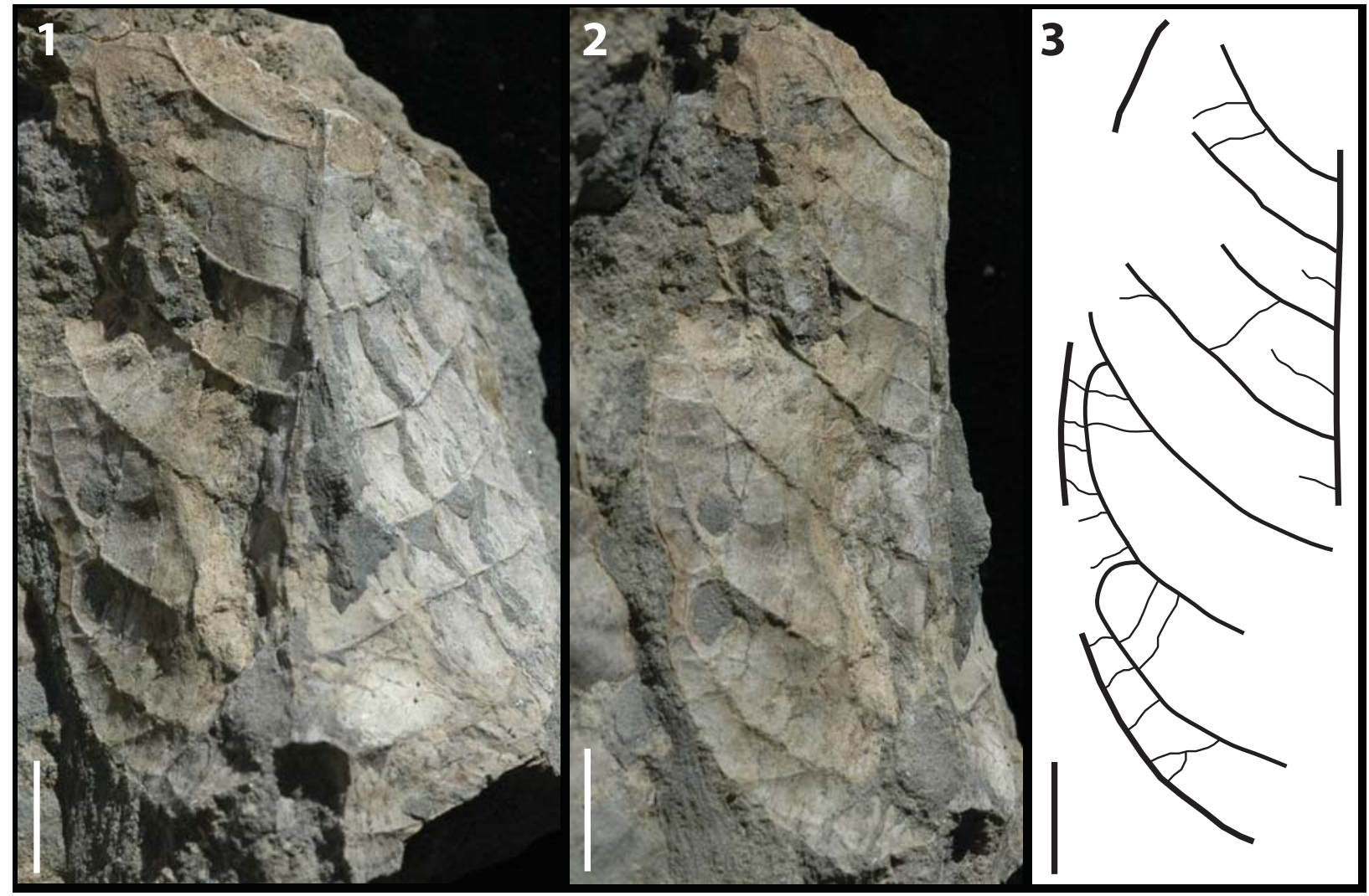

FIGURE 6. 1. KP-05 morphotype exemplar, RU-2010-844, view of whole leaf showing ovate to elliptic shape, pinnate primary venation with a convex to rounded base. Note that the leaf is slightly folded on underlying rock, causing deformation of the overall shape in photo. 2. RU-2010-844, right side of leaf showing brochidodromous secondary venation. 3. Line drawing showing brochidodromous secondary venation, simple agrophic veins, intersecondaries, and opposite sinuous percurrent tertiaries with obtuse angles. All scale bars $=1 \mathrm{~cm}$.

Discussion: The weak brochidodromous secondary vein course, regular and close secondary vein spacing, combined with an elliptic shape and mesophyll size characterize this morphotype.

$$
\text { KP-09 }
$$

Figure 9.1

Description: Blade attachment marginal, laminar size microphyll, L:W ratio 2:1, laminar shape ovate with medial symmetry and basal symmetry. Margin is entire with acute apex angle, straight apex, and unknown base. Primary venation is pinnate. Major secondaries brochidodromous with regular spacing on left side and irregular on right, uniform angles, and decurrent attachment to midvein.

Morphotype exemplar: RU-2010-850 (Figure 9.1) Additional specimens: RU-2010-851

Discussion: The decurrent midvein attachment of the secondary veins, their different vein spacing on opposite sides of the leaf lamina, and the relatively stout primary vein combined with the symmetrical, ovate laminar shape are diagnostic of KP-09.

$$
\text { KP-10 }
$$

Figures 9.2, 9.3

Description: Laminar size microphyll, laminar shape elliptic to ovate with medial symmetry. Margin is entire with acute apex angle, acuminate apex, and unknown base. Primary venation is pinnate. Major secondaries brochidodromous with regular spacing, uniform angles approximately perpendicular to the primary vein, and excurrent attachment to midvein.

Morphotype exemplar: RU-2010-859 (Figure 9.2) Discussion: The roughly perpendicular angle of divergence from the midvein of the secondary venation and the acuminate apex shape distinguish this morphotype.

$$
\text { KP-11 }
$$

Figure 9.4, 9.5

Description: Blade attachment marginal, laminar size microphyll, laminar shape unknown with basal symmetry. Margin is entire with unknown apex, acute base angle, and convex basal shape. Pri- 


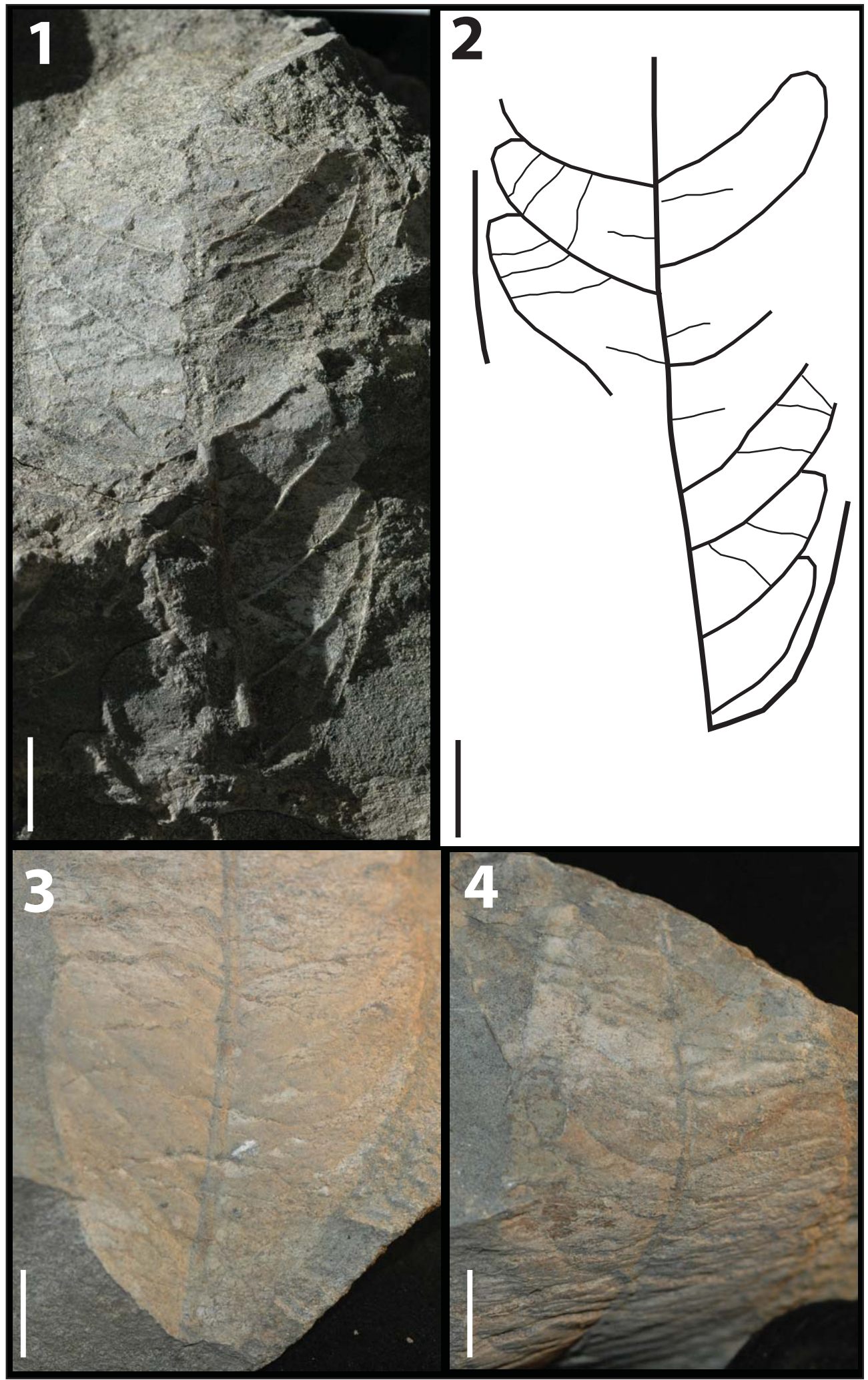

FIGURE 7. 1. KP-06 morphotype exemplar, RU-2010-845, leaf showing brochidodromous secondary venation, oblong laminar shape, and convex base shape. 2. Line drawing showing brochidodromous secondary venation, intersecondaries, and opposite sinuous percurrent tertiaries with angles varying from perpendicular to obtuse. 3. RU-2010-862, basal end of leaf showing convex base shape and brochidodromous secondary venation. 4. RU-2010-862, apical end of leaf showing acute apex angle. All scale bars $=1 \mathrm{~cm}$. 


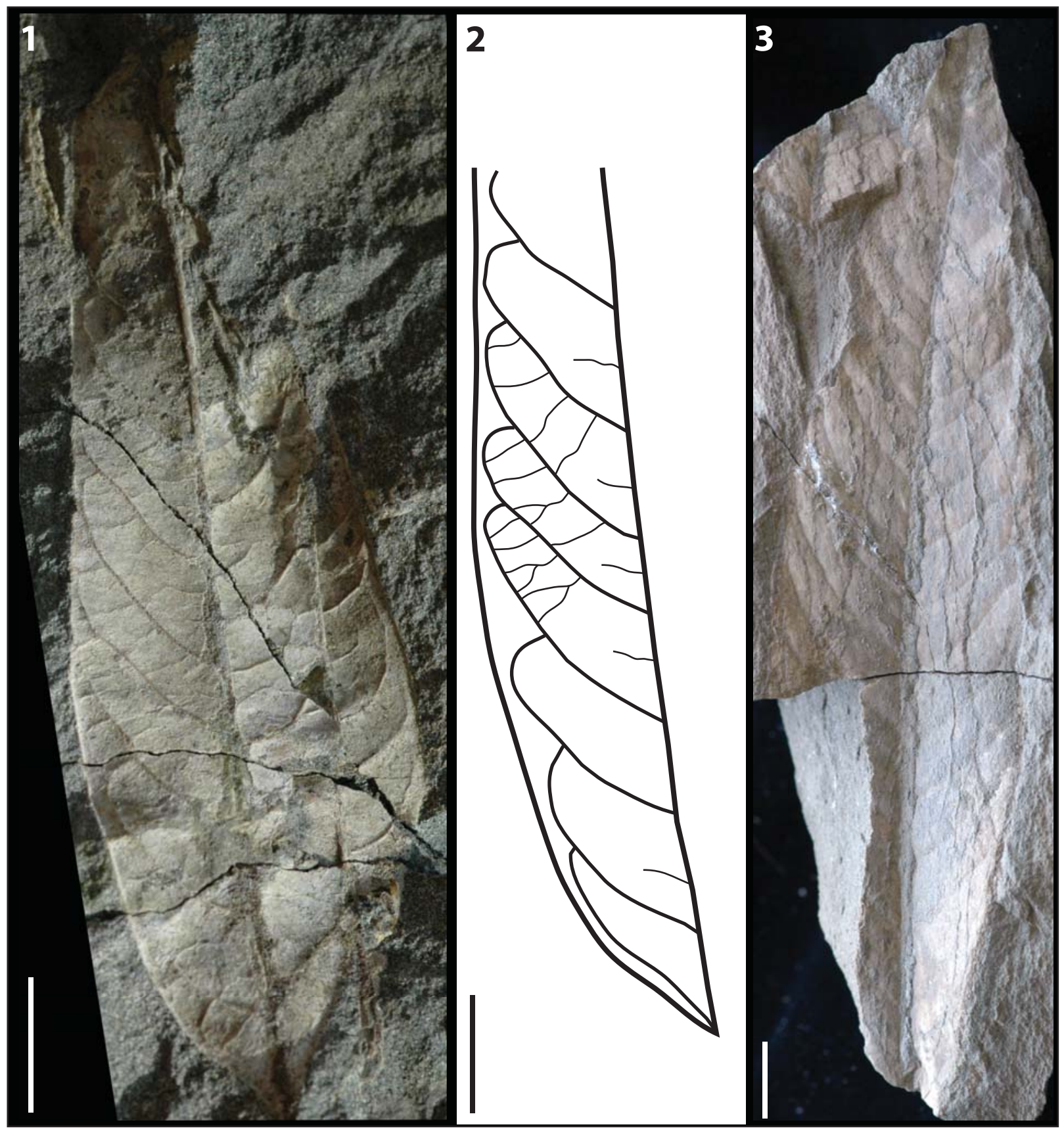

FIGURE 8. 1. KP-07 morphotype exemplar, RU-2010-848, showing ovate laminar shape, concave base shape, pinnate primary venation, and brochidodromous secondary venation. 2. Line drawing showing brochidodromous secondary venation, intersecondaries, and mixed percurrent intercostal tertiaries. 3. KP-08 morphotype exemplar, RU-2010860, showing elliptic to oblong laminar shape, straight apex shape, and weak brochidodromous secondaries with close, uniform, spacing. All scale bars $=1 \mathrm{~cm}$.

mary venation is pinnate with no naked basal veins, three basal veins, and no agrophic veins. Major secondary venation uncertain, but mostly likely eucamptodromous or brochidodromous, vein spacing regular, uniform angles, and excurrent attachment to the midvein. Secondary veins oppo- sitely arranged. Intercostal tertiaries irregular reticulate.

Morphotype exemplar: RU-2010-861 (Figure 9.4) Discussion: The three basal veins, lack of agrophic veins, and irregular reticulate intercostal tertiary vein fabric is characteristic of KP-11. 


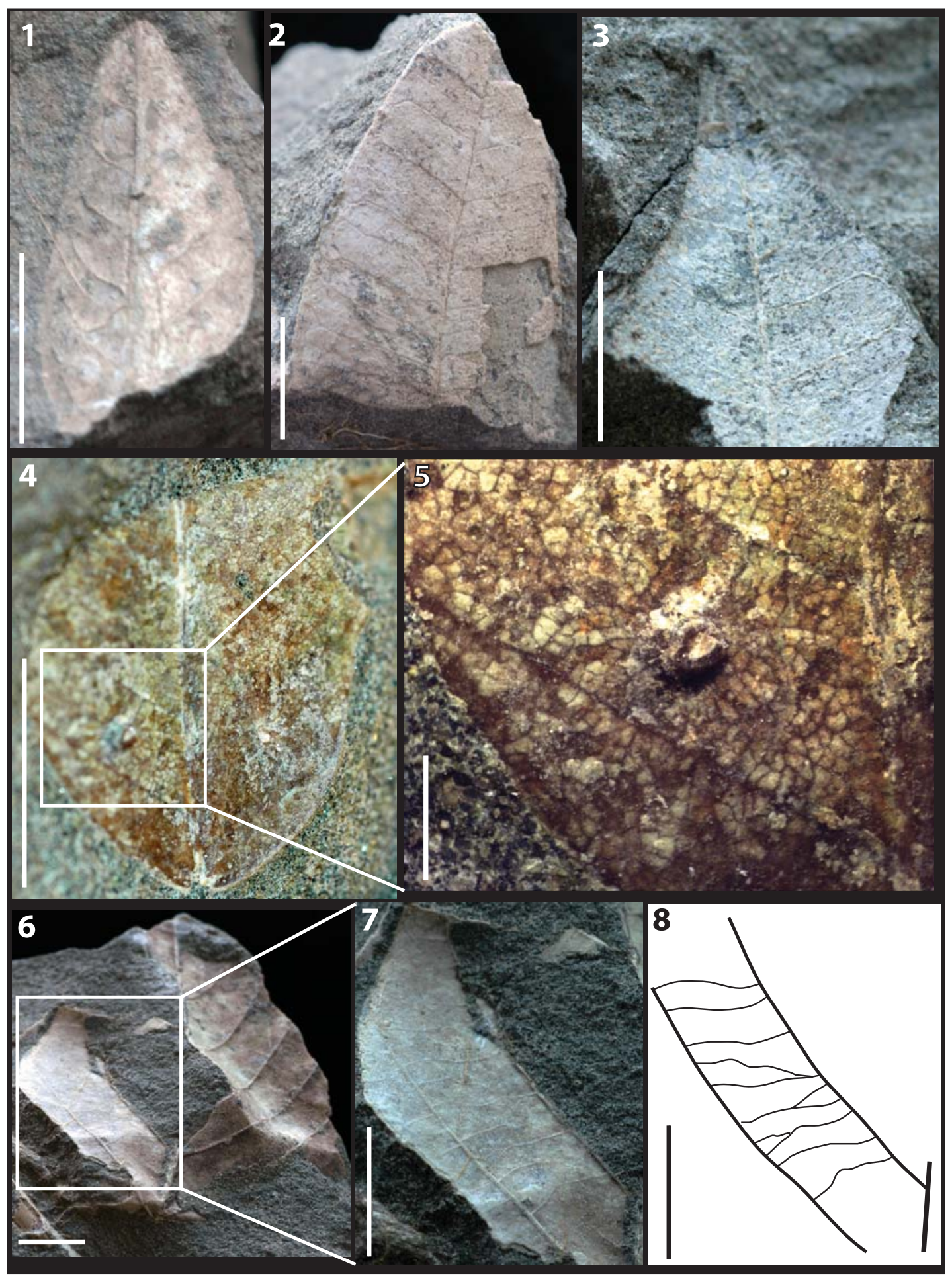

FIGURE 9. 1. KP-09 morphotype exemplar, RU-2010-850, showing ovate laminar shape, straight apex and pinnate primary venation. 2. KP-10 morphotype exemplar, RU-2010-859, showing brochidodromous secondaries with uniform angles and spacing. 3. Counterpart to RU-2010-859 showing acute apex angle and acuminate apex shape. 4. KP-11 morphotype exemplar, RU-2010-861, showing convex base shape and pinnate primary venation. 5. Enlarged portion of 9.4 showing irregular reticulate intercostal tertiaries. Scale $=2 \mathrm{~mm}$. 6. KP-12 morphotype exemplar, RU-2010-863, showing regularly spaced secondaries diverging at a low angle, and a stout midvein. 7. Enlarged portion of 9.6 showing mixed percurrent intercostal tertiaries. 8. Line drawing highlighting the uniform obtuse angles of the intercostal tertiaries. All scales in 9.1-9.4 and 9.6-9.8 = $1 \mathrm{~cm}$. 


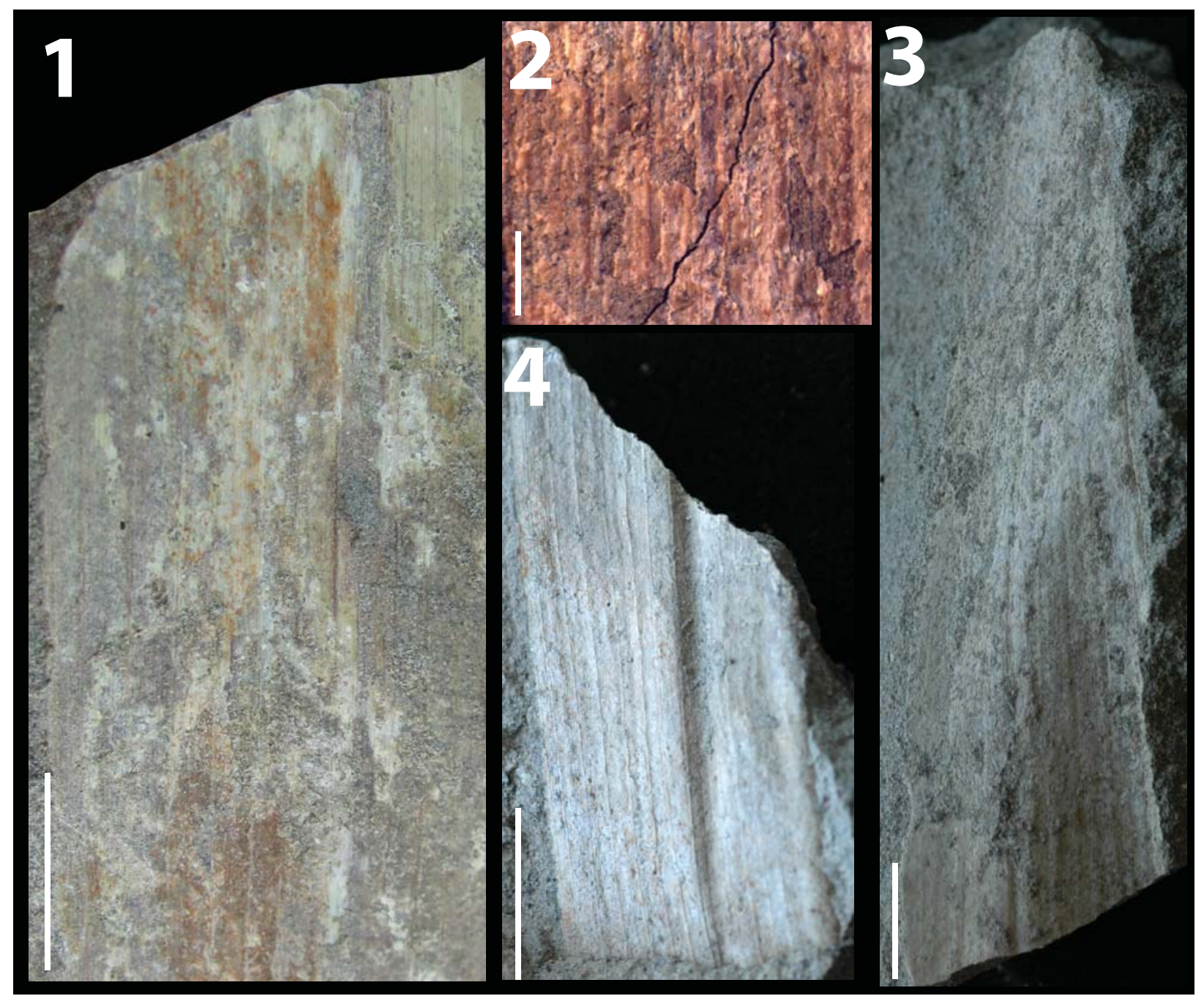

FIGURE 10. 1. KP-13 morphotype exemplar, RU-2010-866, aff. Typha sp. showing major linear veins parallel and evenly spaced. Scale $=1 \mathrm{~cm}$. 2. aff. Typha sp. close up showing minor linear veins running parallel and evenly spaced between major linear veins. Scale $=2 \mathrm{~mm}$. 3. KP-14 morphotype exemplar, RU-2010-867, aff. Phragmites sp. showing parallel major linear veins with midrib. Scale $=1 \mathrm{~cm}$. 4. Additional specimen of KP-14, aff. Phragmites sp., to further demonstrate presence of a midrib, distinguishing KP-14 from KP-13.

\section{$\mathrm{KP}-12$}

Figures 9.6, 9.7, 9.8

Description: Laminar size microphyll to mesophyll, laminar shape ovate. Primary venation is pinnate. Major secondary course unknown with regular spacing, uniform angles, and excurrent attachment to midvein. Intercostal tertiaries mixed percurrent with obtuse angles that remain uniform. Morphotype exemplar: RU-2010-863 (Figure 9.6) Discussion: The uniform percurrent tertiaries, the regular spaced secondaries that diverge from the primary vein at a low angle, the stout midvein, and the ovate shape are characteristic of this morphotype.

\section{Monocotyledonous angiosperms}

$\mathrm{KP}-13$

aff. Typha sp.

Figures 10.1, 10.2

Description: Major linear veins parallel, evenly spaced, with 7-9 minor linear veins running parallel and evenly spaced in between each major linear vein. No cross veins.

Morphotype exemplar: RU-2010-866 (Figure 10.1)

Additional specimens: 2 additional specimens under same catalog number

Discussion: The parallel major veins, absence of cross veins, and the relatively wide lamina matches the description of the vegetative material 


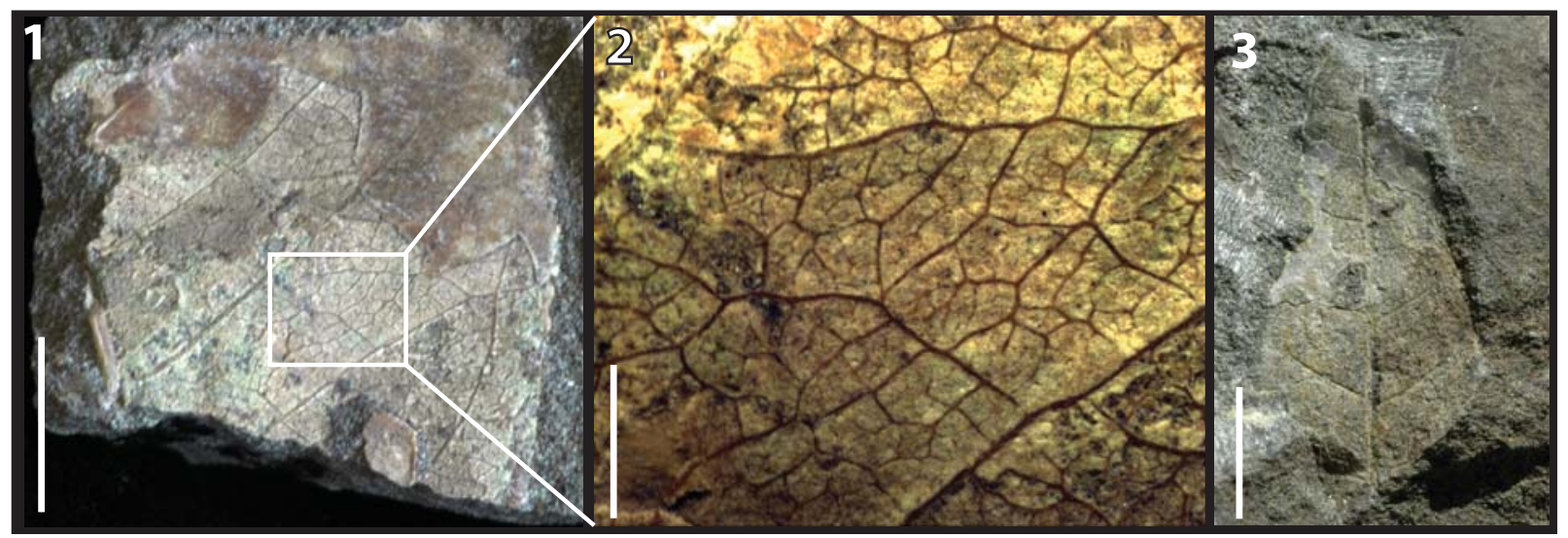

FIGURE 11. 1. KP-15 distinct dicotyledonous fragment, RU-2010-837, showing brochidodromous secondary venation and well preserved higher order venation. Scale bar $=1 \mathrm{~cm}$. 2. Enlarged portion of 11.1 showing intercostal tertiaries irregular reticulate, epimedial tertiaries reticulate, exterior tertiaries variable, and quaternary vein fabric irregular reticulate. 3. KP-16 distinct dicotyledonous fragment, RU-2010-847, showing cladodromous secondary vein course and potential ovate laminar shape. This fragment is potentially the apex of a larger leaf.

of both modern and fossil Typha (e.g., Kubitzki, 1998; Bozukov et al., 2008; Takhtajan, 2009; Marmi et al., 2012), suggesting that this morphotype is a member of the genus Typha. However, because inflorescences are lacking, it is not possible to determine the species. Generally, Typha grows 2-4 m high in wet habitats with permanent or seasonal fresh water (e.g., Kubitzki, 1998).

$$
\text { KP-14 }
$$

aff. Phragmites sp.

Figures 10.3, 10.4

Description: Major linear veins parallel, irregularly spaced, with 5-10 minor linear veins running parallel and evenly spaced in between each major linear vein. No cross veins. Midrib is present.

Morphotype exemplar: RU-2010-867 (Figure 10.3)

Additional specimens: 7 additional specimens under same catalog number

Discussion: The multiple orders of parallel linear veins, the presence of a midrib, and the tapered apex are similar to descriptions of modern Phragmites (Quattrocchi, 2006) suggesting that this morphotype is a member of the Phragmites. However, because reproductive material was not found, it is not possible to classify this morphotype to the species level. Phragmites is commonly found in marshes and riversides (Quattrocchi, 2006).

This morphotype is similar to KP-13, aff. Typha sp.; however the distinct midrib and the presence of minor linear veins between major linear veins in KP-14, aff. Phragmites sp. distinguishes this morphotype.

\section{Distinct dicotyledonous fragments}

$$
\text { KP-15 }
$$

Figures 11.1, 11.2

Description: Margin entire. Major secondaries brochidodromous. Intercostal tertiary veins irregular reticulate. Epimedial tertiaries reticulate. Exterior tertiaries variable. Quaternary vein fabric irregular reticulate.

Morphotype exemplar: RU-2010-837 (Figure 11.1)

Discussion: The higher order venation and brochidodromous secondary veins are characteristic of this leaf fragment. However, the higher order venation preserved here is not as well preserved in many of the morphotypes so at this time it is difficult to determine if KP-15 belongs to a previously described morphotype in our flora or a new taxon.

$$
\text { KP-16 }
$$

Figure 11.3

Description: Blade attachment marginal, laminar size microphyll, L:W ratio 2.5:1, laminar shape ovate with medial symmetry and basal symmetry. Margin is entire with acute apex angle, straight apex, base angle slightly obtuse, convex to rounded base shape. Primary venation is pinnate with no naked basal vein, one basal vein, and no agrophic veins. Major secondaries cladodromous with regular spacing, uniform angles, and excurrent attachment to midvein.

Morphotype exemplar: RU-2010-847

Discussion: The cladodromous secondary vein pattern and ovate shape are characteristic of KP16. However, this specimen has been included as 
a distinct fragment, not a full morphotype, because it is unclear whether this is a whole leaf or a fragment of a leaf apex.

\section{RESULTS AND DISCUSSION}

The assemblage presented here demonstrates that fossil leaves are abundant on Rusinga Island, and that many fossils are well preserved. Our collection has resulted in the description of 12 dicot morphotypes, two monocot morphotypes, and two distinct dicot fragments. Importantly, it represents the first descriptions of fossil leaf morphotypes from Rusinga.

The presence of monocots KP-13 and KP-14, which have probable affinities to Typha and Phragmites (Figure 10), can be used as indicators of paleohabitat. Modern taxa of Typha and Phragmites genera grow in relatively mesic environments, ranging from marshlands to river margins (e.g., Bush and Colinvaux, 1988; Rejmankova et al., 1995; Kubitzki, 1998; Quattrocchi, 2006). The presence of KP-13 and KP-14, in combination with the fluvial sedimentary structures at the collection locality (Figure 3.1), strongly suggests this is a floodplain deposit that was periodically flooded or possibly occasionally submerged in standing water. This paleoenvironmental interpretation is consistent with previously documented streamside or riparian vegetation from the R5 and R117 areas (e.g., Andrews and Van Couvering, 1975; Collinson, 1985; Collinson et al., 2009; Retallack et al., 1995), with the discovery of vertebrate fossil elements from aquatic animals in laterally equivalent strata to our fossil leaf site (unpublished data), and with the abundance of aquatic vertebrates $\sim 5-10 \mathrm{~m}$ stratigraphically above this fossil leaf deposit (Conrad et al., 2013).

The percentage of a flora that is untoothed has long been known to have a strong positive correlation with mean annual temperature (MAT) and various proxies exist to estimate MAT from fossil leaf assemblages (for review see Royer, 2012). Due to our relatively small sample size we refrain from applying any of those analyses here, however, it is worth noting that our assemblage is entirely untoothed. Thus it is plausible that the MAT during the Miocene may have been high; however, more morphotypes are necessary to confidently interpret the paleoclimate of this site.

Salt hoppers are found in layer GM-03 directly above the fossil leaf layer (Figure 3.2) indicating periodic/seasonal sub-aerial exposure and evaporitic conditions leading to the precipitation of evaporites. A high MAT would create the potential for evaporitic conditions given at least seasonal or episodic intervals of limited to no rainfall. This suggests that the paleoclimate during the early Miocene on Rusinga was likely quite warm and experienced prolonged intervals with low to no rainfall.

Leaf size varies amongst different biomes; in woodlands, leaves are primarily microphyll, nanophyll, or leptophyll in size while in forests, leaves are most commonly mesophyll, notophyll, or microphyll sized (Jacobs, 2004). Of the nine morphotypes well enough preserved for area analysis, three were notophyll, four were microphyll, while only two morphotypes were nanophyll. This leaf size distribution, although based on a relatively small sample size, is most consistent with a forest type environment. This is further corroborated by the lack of grasses in our collection, an essential component of woodland environments (Jacobs, 2004), as well as in all previous paleobotantical studies from Rusinga (Chester, 1957; Andrews and Van Couvering, 1975; Collinson, 1985; Collinson et al., 2009). This evidence suggests that patches of more closed, forested environments may have been important components of Rusinga's paleoecology during this time interval.

These paleoenvironmental interpretations represent a single time interval in a much longer period (2-3 Myr) during which fossils were preserved on Rusinga Island. It is important to note that although fossil vertebrates have been found in the Grit Member, including at an outcrop only a few meters away from this study site, there is no direct correlation between the leaves in the Grit Member and the majority of the vertebrate fossil remains collected from localities in the overlying Fossil Bed Member across the island. Nevertheless, this fossil leaf locality underlies the main fossil-producing strata at the R5 locality by only a few meters, suggesting it may represent a similar paleoclimate and paleoenvironment. Additional studies, particularly of other fossil leaf localities on the island, will further resolve the early Miocene vegetation and help to pinpoint the types of environments inhabited by Rusinga's diverse faunal communities.

\section{CONCLUSION}

Our sedimentological and paleobotanical results, coupled with previous work from roughly contemporaneous strata (e.g., Collinson, 1985; Collinson et al., 2009; Ungar et al., 2012; Conrad et al., 2013), indicate a riparian environment that supported a patchwork of woodland and forested biomes in a strongly seasonal, warm climate. This 
suggests both forested and woodland environments were important components of Rusinga's Miocene ecosystem and therefore of the habitats of our catarrhine primate relatives. Continued work to discern paleoenvironments on Rusinga Island is imperative, as small differences in the structure and density of vegetation between woodlands and seasonal forests is critical to help determine how different environmental setting may have influenced the morphological traits of the species inhabiting the early Miocene landscape. Future work on the fossil leaf floras on Rusinga Island should focus on expanding the floral collections and on determining the taxonomic affinities of the morphotypes described here.

\section{ACKNOWLEDGMENTS}

We gratefully acknowledge the Kenyan government and the National Museums of Kenya for facilitating our research. Two grants from the National Science Foundation (BCS-0852609 and BCS-0852515) to K. McNulty, H. Dunsworth, and W. Harcourt-Smith supported this work. Thanks to the McKnight Foundation, University of Minnesota, Baylor University, New York Consortium in Evolutionary Primatology (NYCEP), Saint John's University, and the Rusinga Island Lodge for additional support. We thank $\mathrm{H}$. Dunsworth for her efforts in establishing and maintaining the research on Rusinga and Mfangano and for her comments contributing to this manuscript. We also thank T. Lehmann for the use of his photography equipment, D. Royer for helpful discussion, and J. Olelo for assistance in the field.

\section{REFERENCES}

Andrews, P. and Simons, E. 1977. A new African Miocene gibbon-like genus, Dendropithecus (Hominoidea, Primates) with distinctive postcranial adaptations: Its significance to origin of Hylobatidae. Folia Primatologica, 28:161-170.

Andrews, P. and Van Couvering, J.H. 1975. Paleoenvironments in the East African Miocene. Approaches to Primate Paleobiology, 5:62-103.

Andrews, P., Begun, D. and Zylstra, M. 1997. Interrelationships between functional morphology and paleoenvironments in Miocene hominoids, p. 29-58. In Begun, D., Ward, C., and Rose, M. (eds.), Function, Phylogeny, and Fossils: Miocene Hominoid Evolution and Adaptations. Plenum Press, New York.
Ash, A., Ellis, B., Hickey, L.J., Johnson, K.R., Wilf, P., and Wing, S.L. 1999. Manual of leaf architecture: morphological description and categorization of dicotyledonous and net-veined monocotyledonous angiosperms. Leaf Architecture Working Group: 65 p.

Bestland, E.A. and Krull, E.S. 1999. Palaeoenvironments of Early Miocene Kisingiri volcano Proconsul sites: evidence from carbon isotopes, palaeosols and hydromagmatic deposits, Journal of the Geological Society, 156:965-976.

Bozukov, V., Palamarev, E., and Petkova, A. 2008. The fossil macroflora of the Vulche Pole Molasse Formation (SE Bulgaria). Phytologia Balcanica, 14:173-184.

Bush, M.B. and Colinvaux, P.A. 1988. A 7000-year pollen record from the Amazon Lowlands, Ecuador. Vegetatio, 76:141-154.

Chesters, K.I.M. 1957. The Miocene flora of Rusinga Island, Lake Victoria, Kenya. Palaeontographica Abt. $B, 101: 29-71$.

Collinson, M.E. 1985. Revision of East African Miocene floras: a preliminary report. International Association of Angiosperm Palaeobotany, Newsletter 8:4-10.

Collinson, M.E., Andrews, P., and Bamford, M.K. 2009. Taphonomy of the early Miocene flora, Hiwegi Formation, Rusinga Island, Kenya. Journal of Human Evolution, 57:49-62.

Conrad, J.L., Jenkins, K., Lehmann, T., Manthi, F.K., Peppe, D.J., Nightingale, S., Cossette, A., Dunsworth, H.M., Harcourt-Smith, W.E.H., and McNulty, K.P. 2013. New specimens of 'Crocodylus' pigottis (Crocodylidae) from Rusinga Island, Kenya, and generic re-allocation of the species. Journal of Vertebrate Paleontology, 33:629-646.

Cote, S., Werdelin, L., Sieffert, E.R., and Barry, J.C. 2007. Additional material of the enigmatic Early Miocene mammal Kelba and its relationship to the order Ptolemaiida. Proceedings of the National Academy of Sciences of the United States of America, 104:5510-5515.

Danley, P.D., Husemann, M., Ding, B., DiPietro, L., Beverly, E., and Peppe, D.J. 2012. The impact of the geologic history and paleoclimate of the African Great Lakes on the diversification of East African cichlids. International Journal of Evolutionary Biology, 2012:20 pp. doi:10.1155/2012/57485

Drake, R.E., Van Couvering, J.A., Pickford, M.H., Curtis, G.H., and Harris, J.A. 1988. New chronology for the Early Miocene mammalian faunas of Kisingiri, Western Kenya. Journal of the Geological Society of London, 145:479-491.

Ellis, B., Daly, D.C., Hickey, L.J., Mitchell, J.D., Johnson, K.R., Wilf, P., and Wing, S.L. 2009. Manual of Leaf Architecture. Comstock Publishing Associates, Cornell University Press. Ithaca, New York.

Evans, E.M.N., Van Couvering, J.A., and Andrews, P. 1981. Palaeoecology of Miocene sites in western Kenya. Journal of Human Evolution, 10:99-116. 
Forbes, M.S., Bestland, E.A., Krull, E.S., and Dicker, D.G. 2004. Palaeoenvironmental mosaic of Proconsul habitats: geochemical and sedimentological interpretation of Kisingiri fossil sites, Western Kenya, Journal of African Earth Sciences, 39:63-79.

Jacobs, B.F. 2004. Palaeobotanical studies from tropical Africa: relevance to the evolution of forest, woodland and savannah biomes. Philosophical Transactions of The Royal Society B, 359:1573-1583.

Kent, P.E. 1944. The Miocene beds of Kavirondo, Kenya. Quarterly Journal of the Geological Society of London, 10:85-118.

Kubitzki, K. 1998. Typhaceae, p. 457-460. In Kubitki, K., (ed.), The Families and Genera of Vascular Plants IV: Flowering Plants, Monocotyledons, Alismatanae and Commelinanae (except Gramineae). Springer, Berlin.

Le Gros Clark, W.E. and Leakey, L.S.B. 1950. Diagnoses of East African Miocene Hominoidea. Quarterly Journal of the Geological Society of London, 105:260-263.

Maclnnes, D.G. 1943. Notes on the East African Miocene primates. Journal of the East African and Uganda Natural History Society, 17:141-181.

Marmi, J., Casanovas-Vilar, I., Robles, J.M., Mova-Sola, S., and Alba, D.M. 2012. The paleoenvironment of Hispanopithecus laietanus as revealed by paleobotanical evidence from the Late Miocene of Can Llobateres 1 (Catalonia, Spain). Journal of Human Evolution, 42:412-423.

McCollum, M.S., Peppe, D.J., McNulty, K.P., Dunsworth, H.M., Harcourt-Smith, W.E.H., and Andrews, A.L. 2012. Magnetostratigraphy of the early Miocene Hiwegi Formation (Rusinga Island, Lake Victoria, Kenya). Geological Society of America, Abstracts with Programs, 44:241.

Peppe, D.J., Hickey, L.J., Miller, I.M., and Green, W.A. 2008. A morphotype catalogue, floristic analysis and stratigraphic description of the Aspen Shale Flora (Cretaceous-Albian) of Southwestern Wyoming. Bulletin of the Peabody Museum of Natural History, 49:181-208.

Peppe, D.J., McNulty, K.P., Cote, S.M., Harcourt-Smith, W.E.H., Dunsworth, H.M., and Van Couvering, J.A. 2009. Stratigraphic interpretation of the Kulu Formation (Early Miocene, Rusinga Island, Kenya) and its implications for primate evolution. Journal of Human Evolution, 56:447-461, doi: 10.1016/j.jhevol.2009.02.006

Peppe, D.J., Deino, A.L., McNulty, K.P., Lehmann, T., Harcourt-Smith, W.E.H., Dunsworth, H.M., and Fox, D.L. 2011. New age constraints on the early Miocene faunas from Rusinga and Mfangano Islands (Lake Victoria, Kenya). American Association of Physical Anthropologists. Abstract.
Pickford, M. 1986. Cainozoic palentological sites of Western Kenya. Münchner Geowissenschaftlich Abhandlungen Reihe A: Geologie und Paläontologie, 8:1-151.

Pickford, M. 2004. Revision of the Early Miocene Hyracoidea (Mammalia) of East Africa. Comptes Rendus Palevol, 3:675-690.

Quattrocchi, U. 2006. CRC World Dictionary of Grasses: Common Names, Scientific Names. Eponyms, Synonyms, and Etylmology. CRC Press, London.

Rejmankova, E., Pope, K.O., Pohl, M.D., and ReyBenayas, J.M. 1995. Freshwater wetland plant communities of Northern Belize: Implications for paleoecological studies of Maya wetland agriculture. Biotropica, 27:28-36.

Retallack, G.J., Bestland, E.A., and Dugas, D.P. 1995. Miocene paleosols and habitats of Proconsul on Rusinga Island, Kenya. Journal of Human Evolution, 29:53-91.

Royer, D.L. 2012. Climate reconstruction from leaf size and shape: new developments and challenges, p.195-212. In Ivany, L.C. and Huber, B.T. (eds.), Reconstructing Earth's Deep Time Climate - The State of the Art in 2012. The Paleontological Society Special Papers: 18.

Savage, R.J.G. 1965. The Miocene Carnivora of East Africa. In: Fossil Mammals of Africa, 19. Bulletin of the British Museum (Natural History), 10:241-316.

Schmidt-Kittler, N. 1987. The Carnivora (Fissipedia) from the Lower Miocene of east Africa. Palaeontographica, A197:85-126.

Takhtajan, A. 2009. Flowering Plants (2nd Edition). Springer, Heidelberg.

Thackray, G.D. 1994. Fossil nest of sweat bees (Halictinae) from a Miocene paleosol, Rusinga Island, western Kenya. Journal of Paleontology, 68:795-800.

Ungar, P.S., Scott, J.R., Curran, S.C., Dunsworth, H.M., Harcourt-Smith, W.E.H., Lehmann, T., Manthi, F.K., and McNulty, K.P. 2012. Early Neogene environments in East Africa: Evidence from dental microwear of tragulids. Palaeogeography, Palaeoclimatology, Palaeoecology, 342-343:84-96.

Van Couvering, J.A. 1972. Geology of Rusinga Island and Correlation of the Kenya Mid-Tertiary Fauna. Ph.D. Dissertation, Cambridge University.

Walker, A., Teaford, M.F., Martin, L., and Andrews, P. 1993. A new species of Proconsul from the early Miocene of Rusinga/Mfangano Islands, Kenya. Journal of Human Evolution, 25:43-56. 


\section{APPENDIX}

Catalog of specimen numbers and morphotypes. $\mathrm{DIC}=$ dicotyledonous angiosperm, $\mathrm{MON}=$ monocotyledonous angiosperm, DIC FRAG = distinct dicotyledonous angiosperm. ( ${ }^{*}$ indicates morphotype exemplar).

\begin{tabular}{|c|c|c|}
\hline Affinity & Specimen Number & Morphotype Number \\
\hline DIC & RU-2010-849* & KP-01 (12) \\
\hline DIC & RU-2010-832 & KP-01 \\
\hline DIC & RU-2010-833 & KP-01 \\
\hline DIC & RU-2010-834 & KP-01 \\
\hline DIC & RU-2010-835 & KP-01 \\
\hline DIC & RU-2010-836 & KP-01 \\
\hline DIC & RU-2010-864 & KP-01 \\
\hline DIC & RU-2010-865 & KP-01 \\
\hline DIC & RU-2010-857 & KP-01 \\
\hline DIC & RU-2010-858 & KP-01 \\
\hline DIC & RU-2010-852 & KP-01 \\
\hline DIC & RU-2010-853 & KP-01 \\
\hline DIC & RU-2010-838* & KP-02 (1) \\
\hline DIC & RU-2010-267* & KP-03 (3) \\
\hline DIC & RU-2010-839 & KP-03 \\
\hline DIC & RU-2010-841 & KP-03 \\
\hline DIC & RU-2010-840* & KP-04 (5) \\
\hline DIC & RU-2010-842 & KP-04 \\
\hline DIC & RU-2010-843 & KP-04 \\
\hline DIC & RU-2010-985 & KP-04 \\
\hline DIC & RU-2010-986 & KP-04 \\
\hline DIC & RU-2010-844* & KP-05 \\
\hline DIC & RU-2010-845* & KP-06 (4) \\
\hline DIC & RU-2010-846 & KP-06 \\
\hline DIC & RU-2010-987 & KP-06 \\
\hline DIC & RU-2010-862 & KP-06 \\
\hline DIC & RU-2010-848* & KP-07 (1) \\
\hline DIC & RU-2010-860* & KP-08 (1) \\
\hline DIC & RU-2010-850* & KP-09 (2) \\
\hline DIC & RU-2010-851 & KP-09 \\
\hline DIC & RU-2010-859* & KP-10 (1) \\
\hline DIC & RU-2010-861* & KP-11 (1) \\
\hline DIC & RU-2010-863* & KP-12 (1) \\
\hline MON & RU-2010-866* & KP-13 (3) \\
\hline MON & RU-2010-867* & KP-14 (8) \\
\hline DIC FRAG & RU-2010-837* & KP-15 (1) \\
\hline DIC FRAG & RU-2010-847* & KP-16 (1) \\
\hline DIC & RU-2010-988 & Unidentifiable fragements (41) \\
\hline
\end{tabular}

